\title{
Teljesítménymenedzsment-fókuszú társadalmi innováció a közszférában
}

\section{Performance management focused social innovation in the public sector KuCSMa D. ${ }^{1}$}

\author{
Miskolci Egyetem Gazdaságtudományi Kar, Vezetéstudományi Intézet \\ kucsma.daniella@uni-miskolc.hu
}

Absztrakt

Manapság egyre jelentösebb szerepet kap a teljesitménymenedzsment minden vállalat, szervezet életében. Kutatásom elsösorban a közszolgáltató szektorra fókuszál, hiszen ezen a területen is meg kell felelni számos elvárásnak mind a szervezet érdekeinek, mind a vevök igényeinek vizsgálatakor. Napjainkban a társadalmi innovációs tevékenységnek is jelentös szerepe van, hiszen minden közszolgáltató vállalat szeretne olyan szolgáltatást nyújtani, ami a társadalom elvárásainak megfelel, illetve olyan fejlesztéseket bevezetni, ami a köz érdekeit képviseli. Arra a kérdésre keresem a választ, hogy miért jó, ha egy közszolgáltató szervezet társadalmi innovációs tevékenységet folytat és ez hogyan lehet hatással a szervezet teljesitménymenedzsment rendszerére. A válasz erre a kérdésre egyszerü, hiszen versenyképességet, hatékonyságot, olcsóbb szolgáltatást és társadalmi kohézióerösitést eredményez. Azonban érdemes azt is megvizsgálni, hogy ezen elemek beépitése mellett hogyan lehet a szervezet teljesitményének mérhetöségére is összpontositani,. Munkámban megjelenik, hogy milyen teljesitménymenedzsment módszerek vannak és melyik az, amit a vizsgált egészségügyi szervezetek a gyakorlatban alkalmaznak. A fö célom ezen területek vizsgálatával, hogy közelebb kerüljek az általam megfogalmazott kutatási kérdések tisztázásához, ami a közszolgáltató szervezek teljesitménymenedzsmentjéhez kapcsolható elsösorban.

Kulcsszavak: teljesitménymenedzsment, egészségügy, társadalmi innováció, BSC, közszféra

Abstract. Performance management is becoming more and more important today in the everyday-life of a company or any organizations. Nowadays, the topic of performance evaluation has importance not only in the business sector but also in the public sector. Not only the interests of an organization have to be highlighted, but also those of the employees. In addition to this, in case of public service providers, their customers may have influence on performance perception. Literature in the field of performance management is very diverse but it can be stated that public service organizations have come to the forefront. In this paper a basic research is presented that contributes to the formulation of my research hypothesis.

Keywords: Performance Management; Healthcare; Social Innovation, BSC; Public sector

JEL classifaction: H83, L25, L32, M10

\section{Bevezetés}

Számos publikáció foglalkozik azzal, hogy egy teljesítménymenedzsment rendszer szerepe mennyiben meghatározó egy szervezet életében. Mára nem csak az üzleti szférában kapott helyet ez a terület, hanem

1. https://orcid.org/0000-0002-6518-1901 
a közszolgáltató szervezetek is használják a módszereit és megközelítéseit. A közszféra azonban olyan specifikumokkal rendelkezik, amik miatt a teljesítménymenedzsment alkalmazása más erötérben és módon zajlik, összehasonlítva a versenyszférával (Kaplan, Norton 2002, Horváth 2016). A teljesítménymenedzsment a vezetôi eszköztárnak az egyik alapeleme, így nem csak az üzleti szférában kell ezzel foglalkozni, hanem közszolgáltató szervezetek körében is. A cikkben a közszférára irányuló kutatásaim néhány eredményét foglalom össze és ezek, illetve szakirodalmi elemek felhasználásával logikai úton elemzem a társadalmi innováció lehetőségeinek kihasználhatóságát az említett szektorban. Ezen felül javaslatot teszek egy általános stratégiai térkép, mint keretrendszer alkalmazására mind a teljesítménymenedzsment objektív müködtetése, mind a társadalmi innovációs lehetőségek kihasználhatóságát támogatandó. Jelen cikkel a célom bemutatni, hogy a cikk elején ábrázolt célhierachia eléréséhez mennyiben járul hozzá a jól megválasztott teljesítménymenedzsment. Továbbá fontosnak tartom kiemelten kezelni a kutatás társadalmi innovációs fókuszát is, mert az feltételezem, hogy az hozzájárulhat a kutatás eredményességéhez .

\section{A teljesítménymenedzsment sajátosságai a közszférában}

Minden rendszernek az első feladata egy vagy több, a működés során elérendő cél meghatározása, így mindenképpen érdemes arra fókuszálni, hogy egy közszolgáltató szervezet vizsgálata és értékelése során konkrétan mi az, amire az adott szervezetben figyelni kell.

Első lépésben a szakirodalmi vizsgálatok alapján mutatom be egy közszolgáltató szervezet müködésének céljait és a teljesítményértékelő rendszerének lehetséges módszereit. A vizsgált intézmények vezetőivel mélyinterjúkat készítettem, ami abban segített, hogy egy világos képet kapjak arról, hogy az egészségügyi intézmények milyen teljesítményértékelési rendszert részesítenek előnyben.

A szakirodalmi kutatások során számos definíciót megvizsgáltam, amik kiemelt elemként kezelték és fö célként fogalmazták meg a teljesítményen belül a szervezeti hatékonyságot és eredményességet. Ezeket a célokat azonban értelmeznünk kell, hogy egy közszolgáltató vállalat életében mit jelentenek és milyen módon tudják ezt a két tényezőt elérni és mérni. Így egy általános célhierarhiát állítottam össze, amit az 1. ábra szemléltet.

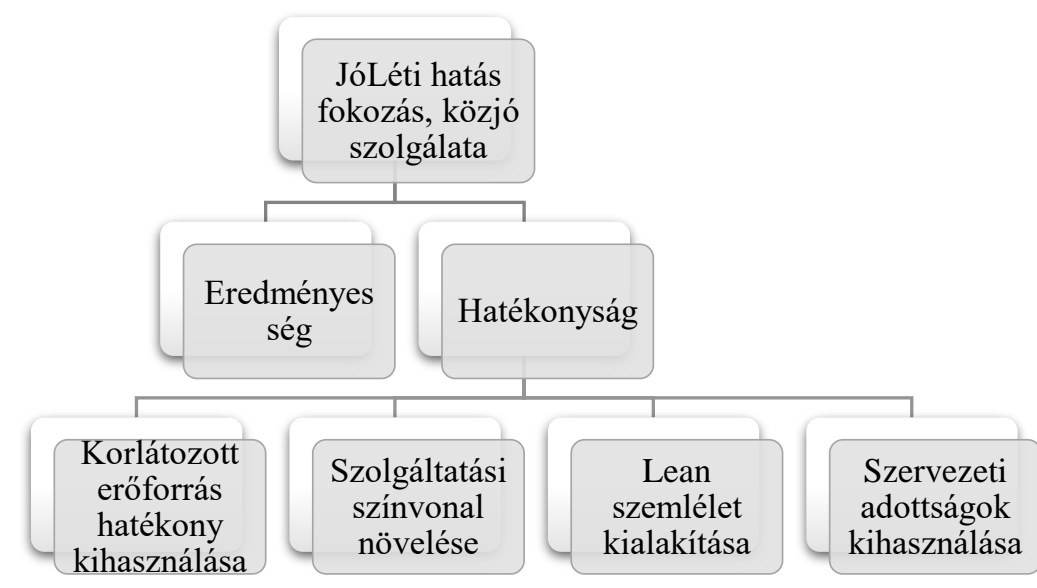

1. ábra: Közszolgáltató vállaltok egy lehetséges célhierarhiája

Figure I. Target hierarchy of performance management of public service organizations

Forrás: Saját szerkesztés, Kocziszky és Veresné 2016 alapján

Az 1. ábrán látható, hogy a legfelső szinten a jóLéti hatás fokozása áll, hisz egy közszolgáltató szervezet esetében ágazattól függetlenül ez a fő cél, így a teljesítménymenedzsment rendszernek is ezt kell 
előtérbe helyeznie (Kocziszky és Veresné 2016). Második szinten a már említett eredményesség és a hatékonyság foglal helyet, azonban ezek további lebontásra szorulnak, így a harmadik szinten olyan elemek jelennek meg, melyek a fent említett magasabb szintü célokat segítik elö. Ezek alapján a következő elemekre szükséges koncentrálni:

- Korlátozott erőforrások kihasználása: itt szándékosan jelenik meg a korlátozott kifejezés, mert egy közszolgáltató szervezet esetén mind a pénzügyi mind az emberi erőforrás, mind a tárgyi eszközök korlátozottak. Erre jó példa az egészségügyi szektor, ahol a kórházak költségkontroll rendszerrel rendelkeznek, ezért a pénzügyi erőforrásaik adott létesítményeken belül korlátozottak. Érdemes azt is megemlíteni, hogy ebben a szektorban nem a profitmaximalizálás a végső cél, de mivel közpénzzel gazdálkodnak a hatékony és gazdaságos müködésre kell koncentrálniuk (Csath 2016).

- Szolgáltatási színvonal emelése: közszolgáltató szervezetről beszélünkés annak az egyik ismérve, hogy a vevőköre a teljes lakosság, azaz a szolgáltatásokkal nemcsak egy bizonyos réteget kell kiszolgálni, hanem valamilyen módon az élete során majdnem mindenki kapcsolatba kerül a szervezeteknek ezzel a típusával (Lannert 2004).

- Lean szemlélet vagy folyamatszemlélet kialakítása: mivel a szervezetek struktúrája is azt mutatja, hogy nem egyszerü egyvonalas szervezetek, ezért a folyamatok koordináltságára és kialakítására is ügyelni kell. A lean szemlélet a szolgáltatások minél inkább veszteségmenetes működését célozza meg alapvetően. A nemzetközi szakirodalom nagy számban számol be egészségügyi jó gyakorlatokról ezen a területen (Molnár, Kerchner 2016).

- Szervezeti adottságok kihasználása: mivel a teljesítménymenedzsment rendszerek ezen elemekre fókuszálnak elsősorban, ezt is kiemelten kell kezelni, mert fontos a jövőkép meghatározásában és az első két szinten meghatározott célok elérése érdekében is.

Egy szervezet elsődleges feladata minden esetben a stratégia meghatározása .A közszolgáltató szervezetek életében ez kiemelt feladat, mivel az egyes ágazatok nem csak eltérő célokkal rendelkeznek, hanem ehhez kapcsolhatóan eltérő értékrendszerrel is. Érdemes leszögezni, hogy olyan rendszer választása javasolt, ami objektív értékelést ad és különösen érdemes arra is figyelni, hogy a kockázatcsökkentés módja is előtérbe kerüljön. A közszféra speciális jellegéből adódóan azt inkább kockázatkerülés jellemzi, mivel sokkal szélesebb a vevőköre.

Kutatásaim során összegyüjtöttem, hogy milyen módszerek alkalmazása a leggyakoribb ezeken a területeken, így a következőkben ezt fogom bemutatni.

\section{Közszolgáltató szervezetek által alkalmazott teljesítményértékelési módszerek}

Mivel egy teljesítménymenedzsment rendszernek a célhierarchiához illeszkedése az elsődleges, így vannak olyan jellegzetességek, amik minden módszerben fellelhetőek. Az 1. táblázat első oszlopa ezen elemeket jeleníti meg. Azonban minden szervezet adottságai heterogének (méret, erőforrások, földrajzi elhelyezkedés), így ehhez kell társítani a megfelelő metódust. Továbbá minden eljárásnak van újdonságtartalma, így a táblázat utolsó oszlopában kerültek megadásra azon újdonságelemek, amik egy rendszer kiválasztásánál a szervezet számára előnyt jelentenek. Érdemes kiemelni, hogy a teljesítménymenedzsment alkalmazásának vizsgálata során nem csak a módszer kiválasztása fontos, hanem vizsgálni kell egy adott nemzet sajátosságait, illetve regionális szinten is eltérőek lehetnek egyegy szervezet tulajdonságai, amik hatással vannak az alkalmazásra. A jellegzetességek oszlopban olyan elemek szerepelnek, melyek minden teljesítményértékelő rendszer ben helyet kapnak. Ezek a tulajdonságok, elemek szükségesek ahhoz, hogy egy rendszer szervezett keretek között jól tudjon müködni. 
.1. Táblázat. Teljesitményértkelö módszerek bemutatása különös tekintettel a közszférára

I. Table Introduction of performance evaluation methods with special regard to the public sector. Forrás: saját szerkesztés: Veresné , Hogya (2011), Czeglédi (2011), Wimmer (2000)

\begin{tabular}{|c|c|c|}
\hline Jellegzetességei & Módszerek & Újdonság \\
\hline $\begin{array}{c}\text { Jövőorientáltság } \\
\text { Hatékonyság }\end{array}$ & $\begin{array}{l}\text { Balanced Scorecard } \\
\text { (BSC) }\end{array}$ & $\begin{array}{l}\text { Szervezeti stratégia egyéni } \\
\text { szintre történő lebontása }\end{array}$ \\
\hline $\begin{array}{c}\text { Eredményesség } \\
\text { Stratégia fó eleme }\end{array}$ & EFQM/CAF & $\begin{array}{l}\text { Ciklikus innovációs } \\
\text { projektekkel fejleszthető }\end{array}$ \\
\hline $\begin{array}{c}\text { Szervezet és egyén } \\
\text { kapcsolata } \\
\text { Magas szintü megfelelés }\end{array}$ & $\begin{array}{c}\text { Szervezeti } \\
\text { Teljesítményértékelő } \\
\text { Rendszer (SZTÉR) }\end{array}$ & $\begin{array}{l}\text { Közszférában/igazgatásban } \\
\text { alkalmazott keretmodell }\end{array}$ \\
\hline \multirow{3}{*}{$\begin{array}{l}\text { Több terület egy idejü } \\
\text { megjelenítése } \\
\text { Kvalitatív és kvantitatív } \\
\text { indikátorok egyidejü } \\
\text { használata }\end{array}$} & Hoshin Menedzsment & $\begin{array}{l}\text { Kritikus folyamatokra } \\
\text { fókuszál, } \\
\text { rendszerfejlesztés PDCA } \\
\text { ciklus }\end{array}$ \\
\hline & Teljesítmény Prizma & $\begin{array}{l}\text { Többcélú optimalizálás } \\
\text { végén a képesség }\end{array}$ \\
\hline & 10 próba & $\begin{array}{c}\text { Minősített } \\
\text { szempontrendszer }\end{array}$ \\
\hline
\end{tabular}

A módszerek összegyüjtésével az volt a célom, hogy megvizsgáljam, melyek azok a módszerek, amiet a közszektorban gyakran alkalmaznak. Emellett azért tértem ki arra is, hogy milyen újdonságtartalommal bírnak, mert az első ábrában megfogalmazott célokhoz a lehető legjobban hozzá kell járulniuk.

Elmondható, hogy minden módszer alkalmazásának vannak előnyei és hátrányai, így nem jelenthető ki egyikről sem, hogy a legjobb. Ugyanakkor vannak olyan speciális ágazatok, amelyek egy adott módszert előnyben részesítenek. Vizsgálataim egészségügyi szektorban végzem és ezen belül is korházakban, ezért a hipotézisem megalapozásához arra kerestem a választ, hogy Magyarországon milyen teljesítményértékelési módszerek alkalmazását részesítik előnyben az egyes kórházak. Ennek a jelentősége csupán abban mérhető, hogy melyik az, ami a leginkább alkalmas az egészségügyi szektor eredményeinek az objektív mérésére. Talán ez az ágazat az, ahol nagyon sok tényező figyelembevétele szükséges, hiszen betegenként és osztályonként is változhatnak a mutatók. Vannak olyan tényezők, amiket érdemes kiemelten kezelni és egy későbbi kutatás során számszerüsíteni.

Emberi erőforrás: itt ki lehet fejezni a számosságot, hogy egy adott intézményben hány és milyen végzettségü munkaerőre van szükség a hatékony szolgáltatás eléréséhez. Elsődleges a munkaerő, mivel e tényező nélkül nincsenek szolgáltatások. Így ha azt vizsgáljuk, hogy melyik az a teljesítménymenedzsment módszer, ami a legjobban hozzájárul ehhez, akkor látható, hogy az a kiegyensúlyozott mutatószámrendszer (Balanced Scorecard - BSC). Ennek oka, hogy a stratégia az egyének szintjére kerül lebontásra (Fabian 2009).

Fontos a tőke is, de egy közszolgáltató meghatározott kerettel dolgozik, azaz nem a nyereségmaximalizálás a legföbb cél, hanem a gazdaságos müködés. Azt is meg kell említeni, hogy 
minden rendszer bevezetésének és fenntartásának vannak költségei, így ezen tényező alapján nehéz lenne egy összehasonlíthatóságot generálni. (Davis, S. and Albright, 2003)

Idő: fontos tényező az idő is, mert minden folyamatban egyfajta optimalizálást kell végrehajtani. Főleg egy egészségügyi intézményben lényeges, mert számos esetben életek is múlhatnak ezen tényezőn. A BSC is koncentrál erre az elemre is, de ebben a tekintetben az EFQM ciklikussága is hatékony segítséglehet (Whitley 1999).

Hét magyarországi kórház teljesítménymenedzsment rendszerét vizsgáltam internetes tartalomelemzés és interjúk segítségével. Elsődlegesen arra kerestem a választ, hogy az egyes intézmények milyen teljesítménymenedzsment megoldásokat alkalmaznak. Ennek a kutatásnak az eredménye alátámasztotta a 2. táblázatban feltüntetett információkat. Az egészségügyi intézmények heterogének voltak, aminek oka, hogy megyei jogú városnál és kisebb városok intézményeiben is vizsgáltam, milyen módszereket alkalmaznak. Az intézmény mérete és elhelyezkedése azért jelentős, mert prioritása van a célok meghatározása során. Nem mindegy, hogy hány ember veszi igénybe a szolgáltatást. A mintám kis minta volt, az eredményeket a 2. táblázat mutatja be. Megállapítható, hogy az egészségügyi intézmények leggyakrabban választott módszere a Balanced Scorecard, mivel ezzel a szervezetet az egyének szintjére le tudja bontani a stratégiát. Ezáltal egy olyan minőségi és egyben mennyiségi mutatószámrendszert tud kialakítani, ami valós képet ad az intézményről. Ezen felül a fejlesztéseket is célirányosan tudja megtenni ezek alapján.

2. táblázat. A vizsgált intézményekben alkalmazott módszerek

Table 2 Methodology applied to the examined institutions

Forrás saját készítés az intézmények weblapjai és stratégiai nyilatkozatai alapján

\begin{tabular}{|c|c|c|}
\hline Kórház & Mérete & $\begin{array}{c}\text { Stratégiában bemutatott és } \\
\text { alkalmazott módszer }\end{array}$ \\
\hline Miskolc & megyei kórház & Balanced Scorecard alapú \\
\hline Zirci Kórház & kis városi kórház & $\begin{array}{c}\text { egyéni teljesítmény } \\
\text { értékelésre zajlik, nincs } \\
\text { konkrét adat a szervezeti } \\
\text { értékelésre }\end{array}$ \\
\hline Csornai Margit Kórház & kis városi kórház & Balanced Scorecard alapú \\
\hline Szent Raffael & megyei kórház & Balanced Scorecard alapú \\
\hline Szent Pantelon & rendelő intézet & Balanced scorecard alapú \\
\hline Bugát Pál & városi kórház & Balanced Scorecard alapú \\
\hline Szent János & Egyesített kórház & $\begin{array}{c}\text { nincs közérdekú } \\
\text { információ, de a jellege a } \\
\text { Balanced Scorecard } \\
\text { alapjaira mutat }\end{array}$ \\
\hline
\end{tabular}

Érdemes megemlíteni, hogy nemzetközi kitekintés során is számos olyan intézmény stratégiai nyilatkozatával találkoztam, amelyek a BSC módszert részesítik előnyben. A BSC jellemzően az ezredforduló óta alkalmazott a közszolgáltató szektorban. Sikeressége abban rejlik, hogy egy vezetési eszköz, ami figyelembe veszi a vállalat nem pénzügyi teljesítményét is a pénzügyi mutatók mellett. Ezen felül előtérbe helyezi a vevőkkel való kapcsolatteremtést és lényegesnek tartja a belső müködéssel és a fejlődéssel kapcsolatos törekvéseket is. Továbbá nem csak a múltbéli eseményekre koncentrál, hanem előtérbe helyezi a jövőbeni lehetőségeket is (Voelker-Raking 2001). 
Érdemes a BSC négy alappillérét olyan mutatószámokkal alátámasztani, ami segítségünkre lehet egy intézmény teljesítménymenedzsment rendszerének a kialakításban és a fent említett három elemre kitérni (emberi erőforrás, tőke és idő). Ezt a következő mérföldkőként határoztam meg kutatásaimban, ahol nevesítem a mutatókat és egy hatékony mutatószámrendszert dolgozok ki.

\section{A társadalmi innováció megjelenése egy közszolgáltató szervezetben}

Elmondható, hogy minden egészségügyi intézmény próbál alkalmazkodni a környezethez és ez a teljesítménymenedzsmentjében is megjelenik. Azonban ennek korlátai vannak és számos olyan terület is hatással van rá, ami nem csak egy szervezet életében jelentős, hanem a társadalmi igények kielégítésére is törekszik. A társadalmi innováció szerepe is jelentős, így a 3. ábrán vázolt mátrix a társadalmi innováció gyakorlati hasznosulását mutatja be a közszférában. Meg kell említeni azonban, hogy a társadalmi innováció definíciós háttere nagyon sokszínü, így ennek a tisztázása is fontos (2. ábra).

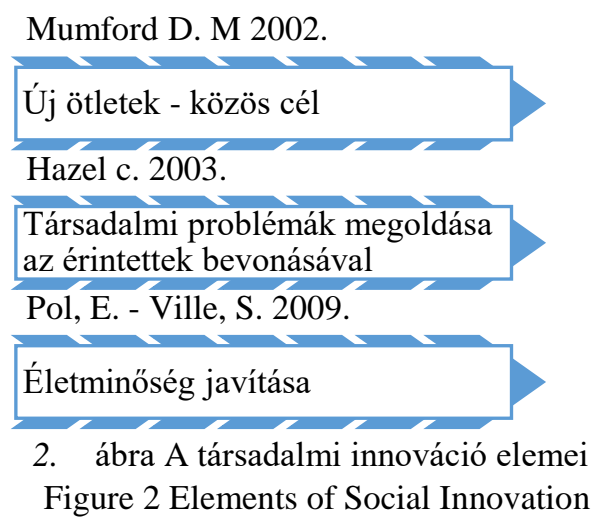

Forrás: Saját szerkesztés Mumford(2002)- Hazel(2003)- Pol(2009)- URBACT(2015)-Anthony (2008) alapján

A 2. ábrán vázolt fogalmi struktúra jól illeszthető a korábban bemutatott célhierarchiához. Három olyan területet emelhetünk ki, amire egy közszolgáltató szervezet esetében hatással lehet a társadalmi innovációs tevékenység (társadalmi megfelelés, működési feltételek hatékonysága, tanulás és fejlesztés) és öt olyan elemet fogalmaztam meg, ami segít ezeknek a területeknek a fejlesztésében és a társadalmi innovációs folyamatok bevezetésében és szervezettségében. A következő kapcsolati mátrixban (3. ábra) láthatjuk, hogy mely elem melyik területen jelenik meg.

\begin{tabular}{|c|c|c|c|}
\hline $\begin{array}{l}\text { Területek } \\
\text { Elemek }\end{array}$ & $\begin{array}{l}\text { Társadalmi } \\
\text { megfelelés }\end{array}$ & $\begin{array}{c}\text { Múködési } \\
\text { feltételek, } \\
\text { hatékonysága }\end{array}$ & $\begin{array}{l}\text { Tanulás és } \\
\text { fejlesztés }\end{array}$ \\
\hline $\begin{array}{l}\text { Bevethetó } \\
\text { erőforrások } \\
\text { növekedése }\end{array}$ & $X$ & $X$ & \\
\hline $\begin{array}{c}\text { Újjajta } \\
\text { szakértelem és } \\
\text { tudás elsajátítása }\end{array}$ & $X$ & $X$ & $X$ \\
\hline $\begin{array}{l}\text { Jobb minőségü } \\
\text { szolgáltatások }\end{array}$ & $X$ & $X$ & \\
\hline
\end{tabular}




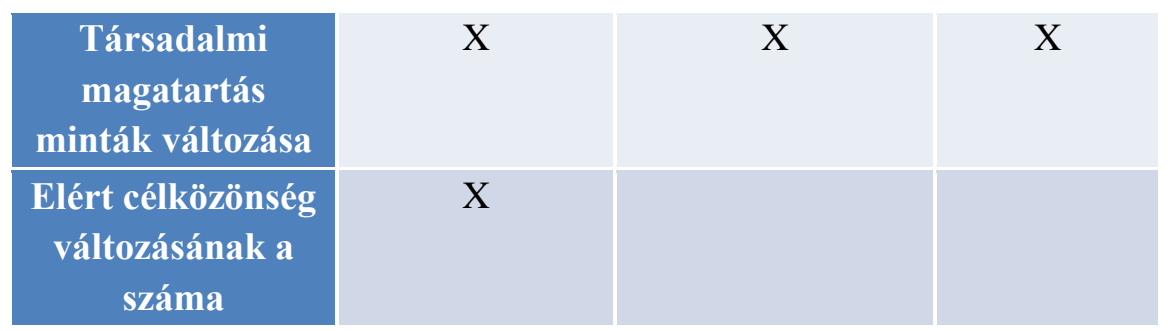

3. ábra A társadalmi innováció hasznosulásának mátrixa a közszférában

Figure 3 Matrix of social innovation exploitation in the public sector

Forrás saját szerkesztés Balaton-Kocziszky-Veresné 2015 alapján

A társadalmi innováció mérése nehéz, mert minden szervezet más és más tevékenységében jelenik meg ez a folyamat. Azonban ha egy egészségügyi intézményben szeretnénk olyan mutatókat keresni, ahol mérhetőség fogalmazható meg, a fent említett öt elem használható. Azt gondolom, hogy a a legfontosabb cél, ahogy a 3. ábrán is látható, az a társadalmi megfelelés. Ezek a tevékenységek egyfajta társadalmi jóllét és elégedettség érdekében jönnek létre, azonban ha egy részletesebb vizsgálatot végzünk számos olyan mutató és elem is hatással lehet erre a területre, ami még ebben a 3. ábrában nincs feltüntetve (Kattel 2013).

A társadalmi innováció kapcsán azt is érdemes megvizsgálni, hogy egy adott régiónak milyen értékei vannak és milyen innovatív tevékenységeket tud ezek kapcsán létrehozni. Ezért a jövőben mindenképpen érdemes egy-egy földrajzi területet kiemelni, megvizsgálni.

\section{Eredmények, összegzés}

Mivel nincs egységes teljesítménymenedzsment rendszer, mindenképp érdemesnek tartom egy olyan integrált rendszer kidolgozását, ami elősegíti az egészségügyi szektor hatékony értkelését. Ágazatokon belül is különbségek tapasztalhatók az intézmények között, de azt gondolom, hogy egy ilyen modell lehetőséget nyújt ezen egyedi adottságok beépítésére is. Kutatások alapján a Balanced Scorcard rendszer négy nézőpontja hatékonynak bizonyult ezen intézmények értékeléséhez. Azt gondolom, hogy a módszer alapjai jók, azonban vannak olyan további elemek, ami korábbi ismeretek és a megfogalmazott célhierarchia alapján beilleszthetőek. Továbbá érdemesnek tartom stratégia térképek elkészítését is, mert ezen információk is hozzá tudnak járulni az integrált rendszerek gyakorlati alkalmazásának sikeres kialakításához és implementációjához, valamint a társadalmi innovációs tevékenységet is meg lehet ebben a szakaszban tervezni. A fent említettek alapján elkészítettem egy javasolt stratégia térképet a vizsgált intézmények stratégia nyilatkozatai alapján. Ebben látható, hogy nagyon nehéz egy ilyen specifikus ágazatban tervezni és az is látható, hogy mennyi elemet kell figyelembe venni, hogy egy intézmény hatékonyan és eredményesen tudjon müködni amellett, hogy a társadalmi igényeket is kielégíti. 


\footnotetext{
Forrás: saját szerkesztés vizsgált stratégia nyilatkozatok alapján
}

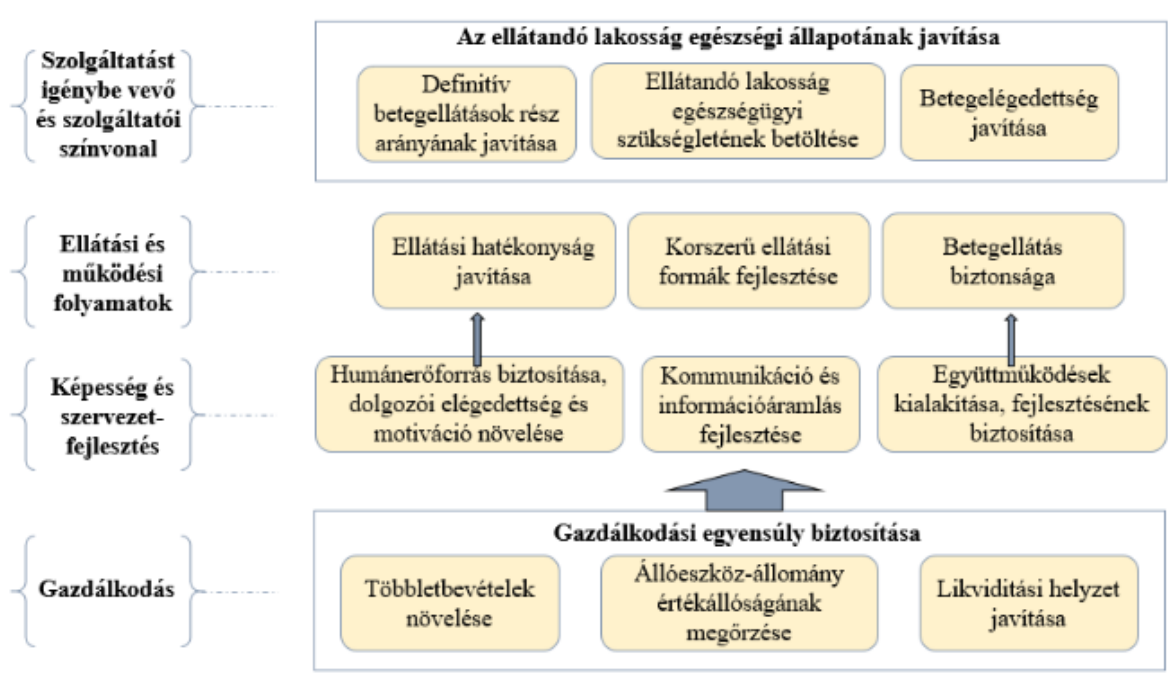

4. ábra: Egy egészségügyi intézmény potenciális stratégiai térképe Figure 4 Strategy map of health care institution Forrás saját szerkesztés kórházak stratégai nyilatkozata alapján

Jelen kutatásom olyan eredményeket mutat be, ami hozzájárulnak ahhoz, hogy egy olyan egységes mutatószám rendszert tudjunk kidolgozni, ami alkalmazása során közszolgáltató szervezetek teljesítménymenedzsmentjében eredményes lehet. Fontos megteremteni a kapcsolatot az 1. ábrában megfogalmazott tényezők és a kiválasztott teljesítménymenedzsment rendszer között. Az általam vizsgált intézményekben Balanced Scorecard alapjú teljesítménymenedzsment müködik, ami jónak mondható, mert a szervezeti startégiát tarja mindenkoron szem előtt. Egy stratégia megtervezées során minden elemet kiemelten tud kezelni a szervezet, többek között a fent említett tőke, humán erőforrás tervezést, és a folyamatok idejét is. Úgy gondolom, hogy ezeket az információkat összevetve megállapítható, hogy az általam felvázolt célhierarchia és a BSC rendszer bevezetése között erős a kapcsolat, mivel ennek a rendszernek a bevezetésével hatékonyabb lesz a szolgáltatás. A lean szemlélet segít a folyamatok kialakításában és a folyamatidők csökkentésében, továbbá a szervezeti adottságok kihasználását és a korlátozott erőforrásokkal való gazdálkodást is megfelelő módon tudja támogatni. További kutatásaimban az ebben a cikkben vázolt stratégia térkép alapján olyan rendszer kidolgozását szeretném célként kitüzni, ami a szervezet specifikussága ellenére is eredményességet hoz és hiánypótló lehet a teljesítménymenedzsment területén.

A kutatást az EFOP-3.6.2-16-2017-00007 azonosító számú, Az intelligens, fenntartható és inkluziv társadalom fejlesztésének aspektusai: társadalmi, technológiai, innovációs hálózatok a foglalkoztatásban és a digitális gazdaságban címü projekt támogatta. A projekt az Európai Unió támogatásával, az Európai Szociális Alap és Magyarország költségvetése társfinanszírozásában valósul meg. 


\section{Irodalomjegyzék:}

Bugat Pal Korhaz (2019). Quality Policy and Mission Statement (In Hungarian: Minőségpolitika és küldetésnyilatkozat), [Online]. Available at http://www.bugatpal.hu/index.php/magunkrol/minosegpolitika-es-kuldetesi-nyilatkozat [cited 1902-2019].

Csath, M. (2016). 'Közintézmények stratégiai menedzsmentje‘. Államtudományi Mühelytanulmányok, 14 , pp. $2-9$.

Czegled, L. (2011). Minőségmenedzsment, [Online]. Available at: http://www.tankonyvtar.hu/hu [cited 20-10-2018].

Davis, S. and Albright, T. (2004). 'An investigation of the effect of Balanced Scorecard implementation on financial performance'. Management Accounting Research, 15(2), pp. 135-153.

Govindarajan, V. and St Gupta, A. K. (1985). 'Linking Control Systems to Business Unit Strategy: Impact on Performance'. Accounting, Organizations and Society, 10(1), pp. 5 1-66.

Horvath, L. (2016). 'Az innováció-kutatás általános tudáshátterének áttekintése'. Budapest: ELTE PPK. pp. 6-22.

Kaplan, R. S. and Norton, D. (2002). 'A Stratégia Központú Szervezet - Hogyan lesznek sikeresek a Balanced Scorecard vállalatok az új üzleti környezetben? 'Budapest: Panem.

Kattel, R., Cepilovs, A., Drechsler, W., Kalvet, T., Lember, V. and Tonurist, P. (2013). 'Can we measure public sector innovation?’ LIPSE Project paper. WP 6 Social innovation indicators. pp. 1-15.

Kazmer, T. (2018). Szent Janos Hospital and North-Buda Joint Hospitals - Organizational and Operational Ruls (In Hungarian: Szent János Kórház és Észak-budai Egyesített Kórházak Szervezeti és Müködési Szabályzat), [Online]. http://www.janoskorhaz.hu/assets/2_1_szmsz.pd [cited 06-11-2018].

Kelly, A. E., Lesh, R. A. and Baek, J. Y. (2008). 'Handbook of Design Research Methods in Education. Innovations in Science, Technology, Engineering and Mathematics Learning and Teaching.' New York: Routledge, Taylor \& Francis.

Kocziszky, Gy., Veres-Somosi, M. and Balaton, K. (2015). Characteristics of Measuring Social Innovation (In Hungarian: Társadalmi innováció mérésének sajátosságai). 'Proceedings of 'Balance and Challenges' $9^{\text {th }}$ International Scientific Conference', Miskolc, Hungary, pp. 288-302.

Kocziszky, Gy. and Veres-Somosi, M. (2016). 'Közszolgálattó szervezetek hatékonyság növelésének lehetőségei.’ Észak- Magyarországi Stratégiai Füzetek, 13(2), pp. 41-56.

Meszaros, L. (2014). Szent Pantaleon Hospital / Clinic Dunaujvaros - Organizational and Operational Rules (In Hungarian: Szent Pantaleon Kórház- Rendelőintézet Dunaújváros - Szervezeti És Müködési Szabályzat), [Online]. Available at http://www.pantaleon.hu/kozerdeku/SZMSZ\%20\%202014.pdf [cited 10-02-2019].

Molnar, V. and Kerchner, A. (2016). 'Application Possibilities of Mean Management in the Public Sector'(In Hungarian: 'A lean menedzsment alkalmazási lehetöségei a közszférában'). Proceedings of the conference 'Technical Science in the Nothern Hungarian Region, Miskolc, Hungary, pp.425432.

Musinszki, Z. (2016). 'Innovations and cost systems trends and ways in the cost accounting'. In: Bezpartochnyi, M. (ed.) Organizational and economic mechanisms of development of the financial system. Riga, Latvia: ISMA University, pp. 209-219. 
Nagy, L. (2015). The Dr. Albert Kenessey Clinic - Strategic Document 2016-2022 (In Hungarian: A Dr. Kenessey Albert Rendelőintézet - stratégiai dokumentum 2016-2022), [Online]. Available at: http://kenessey.hu/kozadatok/strategia [cited 15-10-2018].

Pol, E. and Ville, S. (2009). 'Social innovation: buzz word or enduring term?' The Journal of SocioEconomics, 38 (6), pp. 878-885.

State Audit Office of Hungary. (2015). Jelentés a központi alrendszer egyes intézményei pénzügyi és vagyongazdálkodásának ellenőrzéséről - Zala Megyei Kórház, [Online]. available at http://www.zmkorhaz.hu/doc/nyilvadat/aszellenorzes2015.pdf [cited 21-10-2018]

State Audit Office of Hungary. (2011). Jelentés Miskolc Megyei Jogú város Önkormányzata pénzügyi helyzetének ellenőrzéséről (43/3), [Online]. Available at: https://asz.hu/storage/files/files/\%C3\%96sszes\%20jelent\%C3\%A9s/2011/1139j000.pdf?ctid=730 [cited 16-10-2018].

URBACT II Capitalisation (2015): Social innovation in cities. Apr. 2015

Veres-Somosi, M. and Hogya, O. (2011). 'Teljesitménymenedzsment.' Budapest: Nemzeti Tankönyvkiadó.

Vermes, T., Varsanyi, A., Valler, I. and Horvath, S. (2015). Zirc Erzsebet Hospital / Clinic Development Plan 2015-2020 (In Hungarian: Zirci Erzsébet Kórház / Rendelőintézet - Fejlesztési terv 2015-2020). [Online]. Available at https://www.zirckorhaz.hu/?page_id=1000 [cited 12-102018].

Voelker, K. E. , Rakich. J. S. and French. G. R. (2001). 'The Balanced Scorecard in Healthcare Organizations: A Performance Measurement and Strategic Planning Methodology'. Hospital Topics, 79(3), pp. 13-24.

Winiczai, Z., Abraham, P. and Nemeth-Borsodi, I. (2017). Strategic Goals for the Year 2018 in the Csornai Margit Hospital (In Hungarian: 2018. évi stratégiai célok a Csornai Margit Kórházban), [Online], Available at: http://www.margitkorhaz.hu/pdf/2018_evi\%20strategia_terv.pdf [cited 1610-2018].

Wimmer, A. (2000). 'A vállalati teljesítménymérés az értékteremtés szolgálatában, a müködési és a pénzügyi teljesítmény kapcsolatának vizsgálatában', [Online]. Available at: http://unipub.lib.unicorvinus.hu/32/1/10_mht_wimmer.pdf [cited 25-05-2018].

Whitley, R. (1999). 'Firms, institutions and management control: the comparative analysis of coordination and control systems'. Accounting, Organisations and Society, 24(5/6): 507-524. 